\title{
TRACE AND HEAVY ELEMENTAL CONCENTRATION ANALYSIS OF BANGLADESHI MEDICINAL PLANTS USING PROTON INDUCED X- RAY EMISSION TECHNIQUE.
}

\author{
${ }^{* 1}$ S. M. Fahad, ${ }^{2}$ Md Zakir Hossain, ${ }^{1}$ Shah Sultan Ashrafi, ${ }^{5}$ F. A. Sabbir Ahamed, ${ }^{4}$ Sanjida \\ Sultana Reya, ${ }^{1}$ Md. Hazrat Ali, ${ }^{6}$ Ishrat Jahan, ${ }^{3}$ Md. Joynal Abedin, ${ }^{2}$ Mohammad Obaidur Rahman
}

\author{
${ }^{1}$ Department of Chemistry and Physics, Gono University, Bangladesh \\ ${ }^{2}$ Department of Physics, Jahangirnagar University, Bangladesh \\ ${ }^{3}$ Accelerator Facility Division, Bangladesh Atomic Energy Commission, Bangladesh \\ ${ }^{4}$ Department of Computer Science and Engineering, Daffodil International University, Bangladesh \\ ${ }^{5}$ Department of Physics, International University of Business Agriculture and Technology, Bangladesh \\ ${ }^{6}$ Department of Computer Science and Engineering, Southeast University, Bangladesh \\ *Corresponding author
}

DOI: https://doi.org/10.51193/IJAER.2021.7102

\begin{abstract}
The medicinal plants grown in Bangladesh have pharmacological importance and the raw material source that may be applied to produce different drugs in pharmaceutical industries. The major and trace elements in medicinal plants are essential nutrients known as minerals in the human body. In this study, Curcuma zedoarya (leaf), Curcuma zedoaria (bough), Euphorbia hirta (leaf), Mimosa pudica (bough), and Mimosa pudica (root) were investigated using the Proton Induced X-ray Emission (PIXE) technique. The samples (pellets) were irradiated by $2.5 \mathrm{MeV}$ proton beam of $3 \mathrm{MV}$ Van de Graff accelerator. The spectrum data were collected using PIXE data acquisition setup \& MAESTRO-32 and analyzed by GUPIX/DAN-32 software technique. Specifically, the goal of this research was to identify concentration of heavy and trace elements that are important for many physiological and biochemical processes for human beings. Interestingly, $\mathrm{Ca}$ and $\mathrm{S}$ showed the highest concentration, while $\mathrm{Zn}$ and $\mathrm{Ni}$ revealed the lowest concentration in medicinal plants. The results have been compared with allowable limits of IAEA-V-10 and IAEA-359. Owing to these reports, the uses of these plants are not entirely protected from health risks.
\end{abstract}


International Journal of Agriculture and Environmental Research

ISSN: 2455-6939

Volume: 07, Issue: 01 "January-February 2021"

Further studies would give adequate information to assess the importance of medicinal plants that may contribute to human health.

Keywords: Medicinal plants, Particle Induced X-ray Emission (PIXE), Van de Graff accelerator, Trace Elements and MAESTRO-32

\section{INTRODUCTION}

Medicinal plants are well known for medicinal purposes, and people use them as drugs to treat ancient disorders, nutrition, or nutritional issues. It is a distinct category of natural commodity that is often valuable because of its beneficial effect on human well-being. These medicinal plants may combine different chemical compounds in order to perform essential biological functions due to their diverse effect on human quality of life; they may have a significant role to play [1] in curing several diseases. Trace components play essential metabolic functions. Analysis of all trace elements has developed a thriving value for both the diverse role of all natural, environmental and agricultural goods in human health. The element, $\mathrm{Fe}, \mathrm{Zn}, \mathrm{Cu}, \mathrm{Mn}, \mathrm{Ni}$, $\mathrm{Co}$, Mo, Se, Cr, I, F, Sn, Si, V, and As, is called trace element, where the concentration of any substance in an element is deficient. These elements are also known as micronutrients, typically an active enzyme [2], a catalytic protein formed by cells. The synthesis of hormones, vitamins, proteins, DNA, and RNA is also a part of certain essential trace elements. Any weakness or rise in their average cell level can lead to physiologic problems [3] and diseases like a cavity, anemia, cancer, cardiovascular conditions, obesity, osteoporosis, arthritis, and so forth. Awareness of medicinal plant Major and trace elements are essential for proper diagnosis and treatment planning. Bangladesh has an immense diversity of herbs [4][6], many of which are used for the therapeutic purpose. In Bangladesh, medicinal plants are commonly used in urban communities and as drugs to escape the disease. Concerning toxicity and availability of health care [7], understanding the quantities of major and trace elements of medical plants is highly important. Several Nuclear Analytical methods were developed to detect elemental concentrations. Nuclear methods such as X-ray fluorescence (XRF) [8], Neutron Activation Analysis (NAA), Mass Spectrometry, Proton Induced Gamma Emission (PIGE), and Atomic Absorption Spectrophotometer (AAS) were developed [9] to determine the elemental composition. Using proton-induced X-ray emission techniques (PIXE) [10][11] has recently evolved as they have non-invasive and multi-elemental analysis method; currently, this technique has been used for a widespread variety of material analysis problems. Because of its great advantages [12], plant materials fit for PIXE analysis. The trace elements can be evaluated over short periods in large numbers of samples in one run.

Moreover, preparing plant samples for analysis is very easy. In the past ten years, IBA methods have been successfully used for elemental research in medicinal plants [13][14]. The purpose of 
the study is to use PIXE to determine elements in the medicinal plants of Bangladesh and find a supposed correlation between the elemental compositions by their traditional therapeutic usage and assess the importance of these elements plant species to the recommended dietary intake (DRI). This study has been successfully performed using the proton beam energy of $2.5 \mathrm{MeV}$ and the beam current range of (10-20) nA for sample irradiation and used the MAESTRO-32 for data acquisition to precisely investigate the profile in several samples and achieve information on the samples' overall elemental composition. Curcuma zedoarya (leaf), Curcuma zedoaria (bough), Euphorbia hirta (leaf), Mimosa pudica (bough), and Mimosa pudica (root) are selected under PIXE experiments for this research works. These five plants are used domestically to preserve immunity and cure common diseases.

\section{EXPERIMENTAL}

\subsection{Sample Preparation}

The Memmert Schutzard Oven (Model No. DIN 40050-IP20, range 『 200】^0C) has been used for sample drying purposes. The temperature range of the oven kept $80^{\circ} \mathrm{C}$. The different periods needed to dry different samples. Bough and Root samples need to dry 24 hours and for leaves 72 hours. Their weight was taken. The measuring procedure has been replicated until the electronic balance indicates that the samples are water-free. The weighting process is continuous. The samples are free of humidity at this point. The Agate Mortal Pester is used to grind samples into a fine powder and washing the pester with acetone after each sample has been grinded (CH3-CO-CH3) to prevent cross-contamination. In each pellet, a sample of 0.25 grams of polyvinyl alcohol (2ure-C2H4O)n and 90-100 kg / Cm2 were combined with two drops of polyvinyl alcohol 2ur Synthesis. The pellets had diameters of $10 \mathrm{~mm}$ and thickness of $1 \mathrm{~mm}$. Then, all of the pellet samples were placed in the oven that had dried at the temperature of $200^{\circ}$ $\mathrm{C}$, and the others were put in the freeze-drying, which was dried in it, to keep away the polyvinyl alcohol which was used to make the pellets thin and to keep the powder together. Finally, the samples were labeled in pellet caskets and held to prevent the contaminants in vacuum desiccators. 
Table 1: The scientific name, Part analyzed and Medicinal uses of selected medicinal plants

\begin{tabular}{lll}
\hline Scientific name & Part analyzed & Medicinal Uses \\
\hline Curcuma zedoaria & Leaf & $\begin{array}{l}\text { Inflammation, pain, and a variety of skin ailments } \\
\text { including wounds, as well as menstrual irregularities } \\
\text { and ulcers. }\end{array}$ \\
Curcuma zedoaria & Bough & $\begin{array}{l}\text { Heal Cough and cold, sticky taste in the mouth, treat } \\
\text { fevers and bronchitis. }\end{array}$ \\
Euphorbia hirta & Leaf & $\begin{array}{l}\text { Used in the treatment of cancer, diarrhea, dysentery, } \\
\text { intestinal, asthma, bronchitis, wounds, kidney stones } \\
\text { and abscesses etc. }\end{array}$ \\
Mimosa pudica & Bough & $\begin{array}{l}\text { Very effective in controlling bacterial and fungal } \\
\text { infections. }\end{array}$ \\
Mimosa pudica & Root & $\begin{array}{l}\text { Used in treating bleeding disorders like menorrhagia, } \\
\text { excessive uterine bleeding, and dysentery with blood, } \\
\text { mucus and piles. }\end{array}$ \\
\hline
\end{tabular}

\subsection{Proton Induced X-ray Emission}

PIXE is an energetic proton dependent on atomic fluorescence and the study was conducted by measurement of the sample's x-ray characteristics. It was well adapted to measure major, minor, and trace element in different sample matrices such as biomedical [15], environmental, agriculture and industrial samples. In the PIXE technique, this characteristic X-rays were detected using a Lithium-drifted Silicon [Si (Li)] detector. The identity of different elements present in the sample can be determined by a dispersive energy study of the detector signals and, more significantly, by evaluating the charges. i.e. The concentrations of the components can be precisely quantified by the number of incoming particles. [16][17]. This is truly multi-elemental technique and can identify elements from $\mathrm{Na}$ (this lower limit is set by inefficiency of the X-ray detectors below Na X-ray) and up through the rest of the periodic table. Applications of this technique are widely ranging and diverse. In AF Lab. Atomic Energy Centre, Dhaka laboratory is routinely being used for the analysis. 
International Journal of Agriculture and Environmental Research

ISSN: 2455-6939

Volume: 07, Issue: 01 "January-February 2021"

\subsection{Experimental Set up}

In the present analysis, the elemental concentration measurements have been done with $2.5 \mathrm{MeV}$ proton beam energy collected from the 3 MV Van de Graff Accelerators using PIXE. The overall analysis was carried out in the vacuum chamber. The vacuum in the order of $2.0 \times 10^{-5} \mathrm{mbar}$ in the chamber is frequently reached. The turbopump is used for emptying the accelerator tube the beamline. The IBA scattering mechanism uses a small turbopump for vacuum activities. Typical $\mathrm{x}$-rays were measured in the beamline using a $\mathrm{Si}(\mathrm{Li})$ detector. To transform analog data into digital, the detector was linked with a multichannel analyzer (MCA). There were two reasons for using the $170 \mu \mathrm{m}$ thick Mylar absorber in front of the X-ray detector. The first one is to avoid radiation exposure from the dispersed high-energy particles from the sample, and finally, the $\mathrm{X}$ ray detector count rate is decreased, which is essential to reduce the pulse pile and the dead time during the data analysis process.[2]. Loss of secondary electrons, loss of dispersed particles, and charge development in protecting specimens were the most imperative reasons considered during charge analyses. The charge was measured in the Faraday cup, placed after the chamber at the end of the beamline. PIXE analysis detects highly z elements ( $\mathrm{S}, \mathrm{Cl}, \mathrm{K}, \mathrm{Ca}, \mathrm{Fe}, \mathrm{Cu}, \mathrm{Zn}, \mathrm{Ga}, \mathrm{Br}$, $\mathrm{Ru}, \mathrm{Pb}$, etc.) and Provides the precise concentration of most sample components with high precision

\subsection{Data Acquisition}

We collected data on the various elements using the MAESTRO-32 software for the PIXE process, through measurements of the spectrum peaks. The spectrum was measured using GUPIX/ DAN-32 tools to calculate the concentration. The collected information was stored in the predefined folder during a special GUPIX file format with some required header information. Thus, data were collected in PIXE analysis. In the PIXE technique qualitative study of various elements in a spectrum (Fig.1-Fig.5) was achieved by detecting the high peak of the related Xray energy emanating from the particular $\mathrm{x}$-ray line of the element in the spectrum. One or two $\mathrm{X}$-ray lines are typically adequate for a good qualitative identification of an entity. 


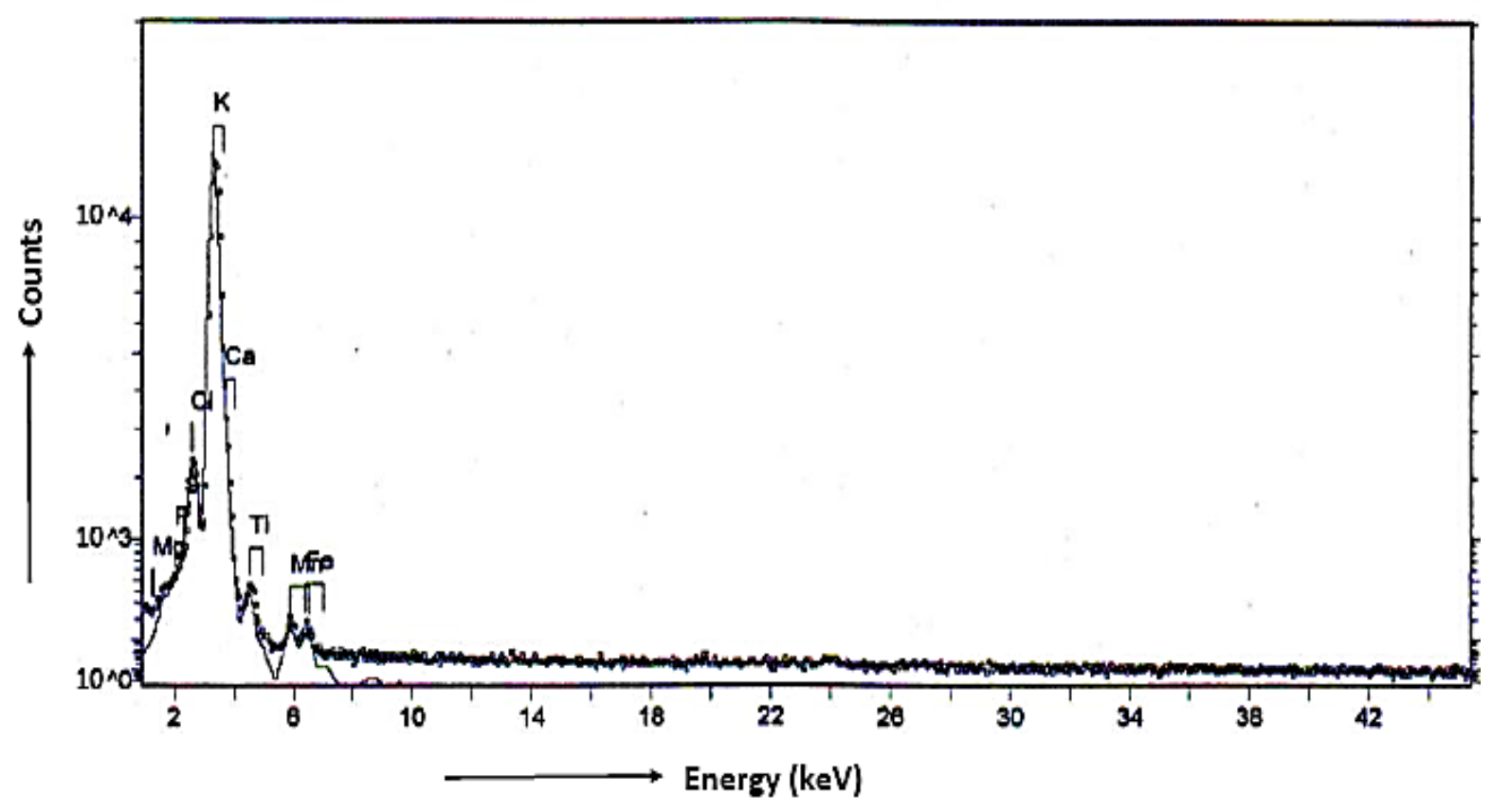

Figure 1: A Typical PIXE spectrum of Curcuma zedoaria (leaf).

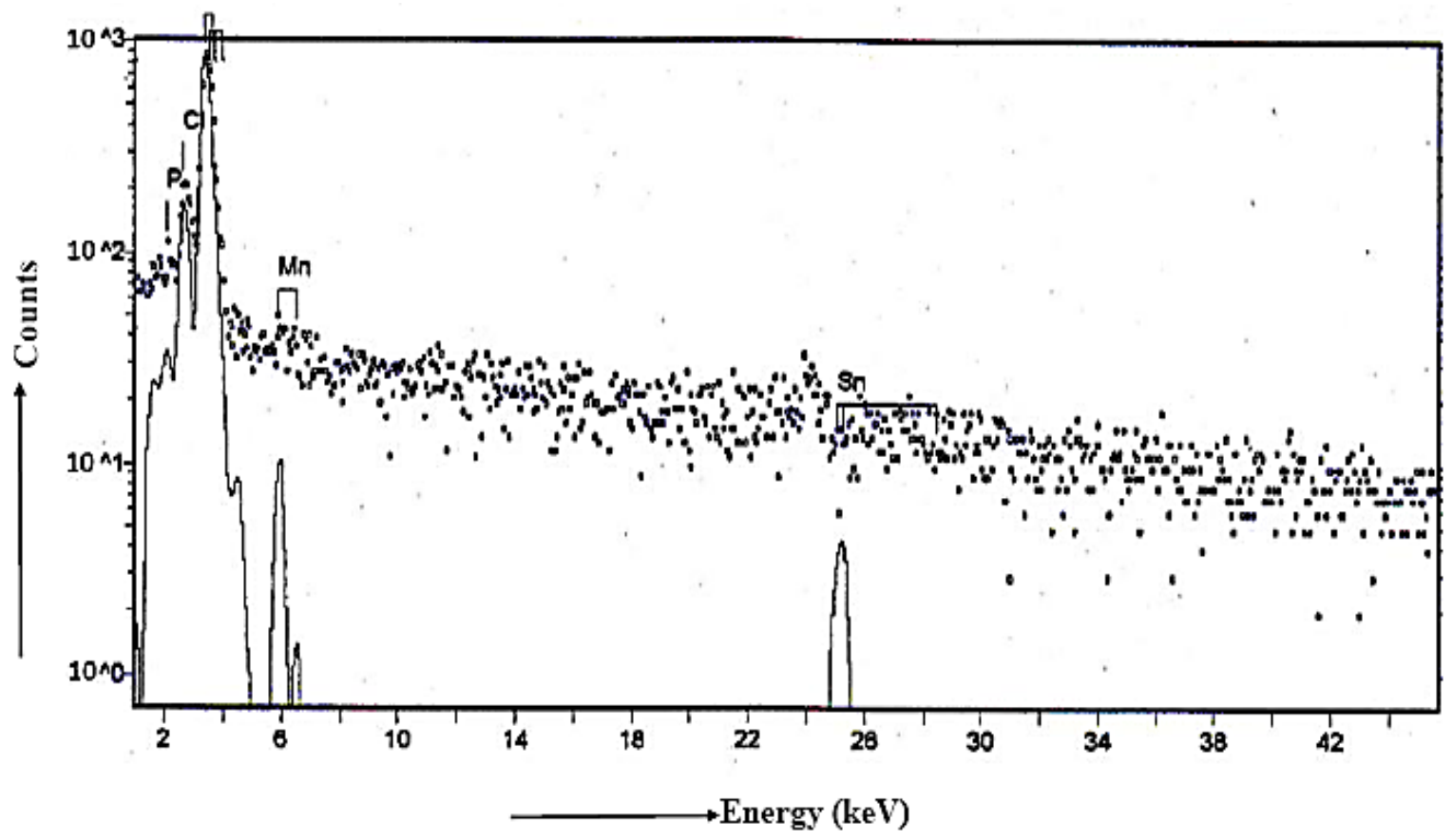

Figure 2: A Typical PIXE spectrum of Curcuma zedoaria (bough). 


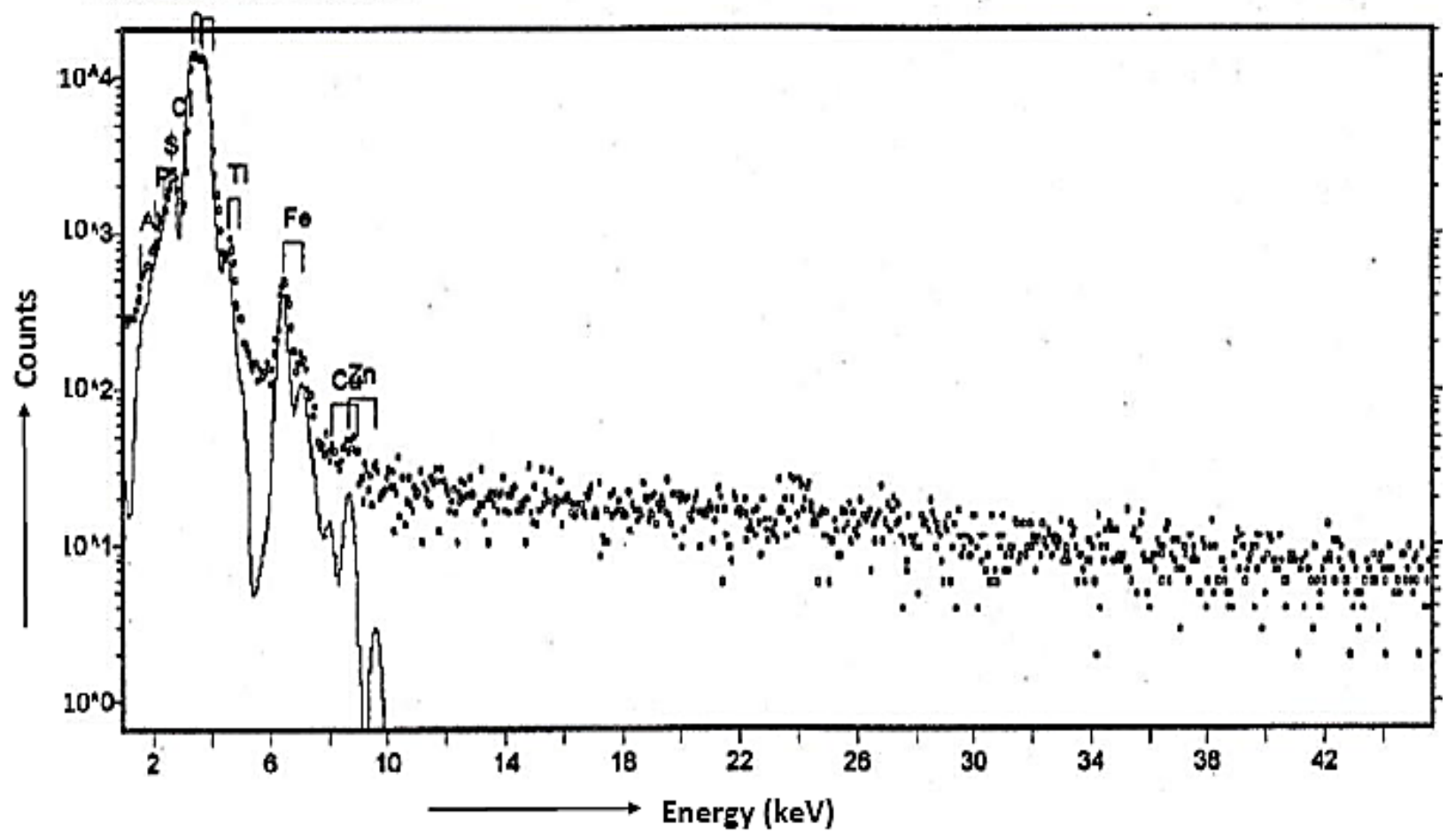

Figure 3: A Typical PIXE spectrum of Euphorbia hirta (leaf).

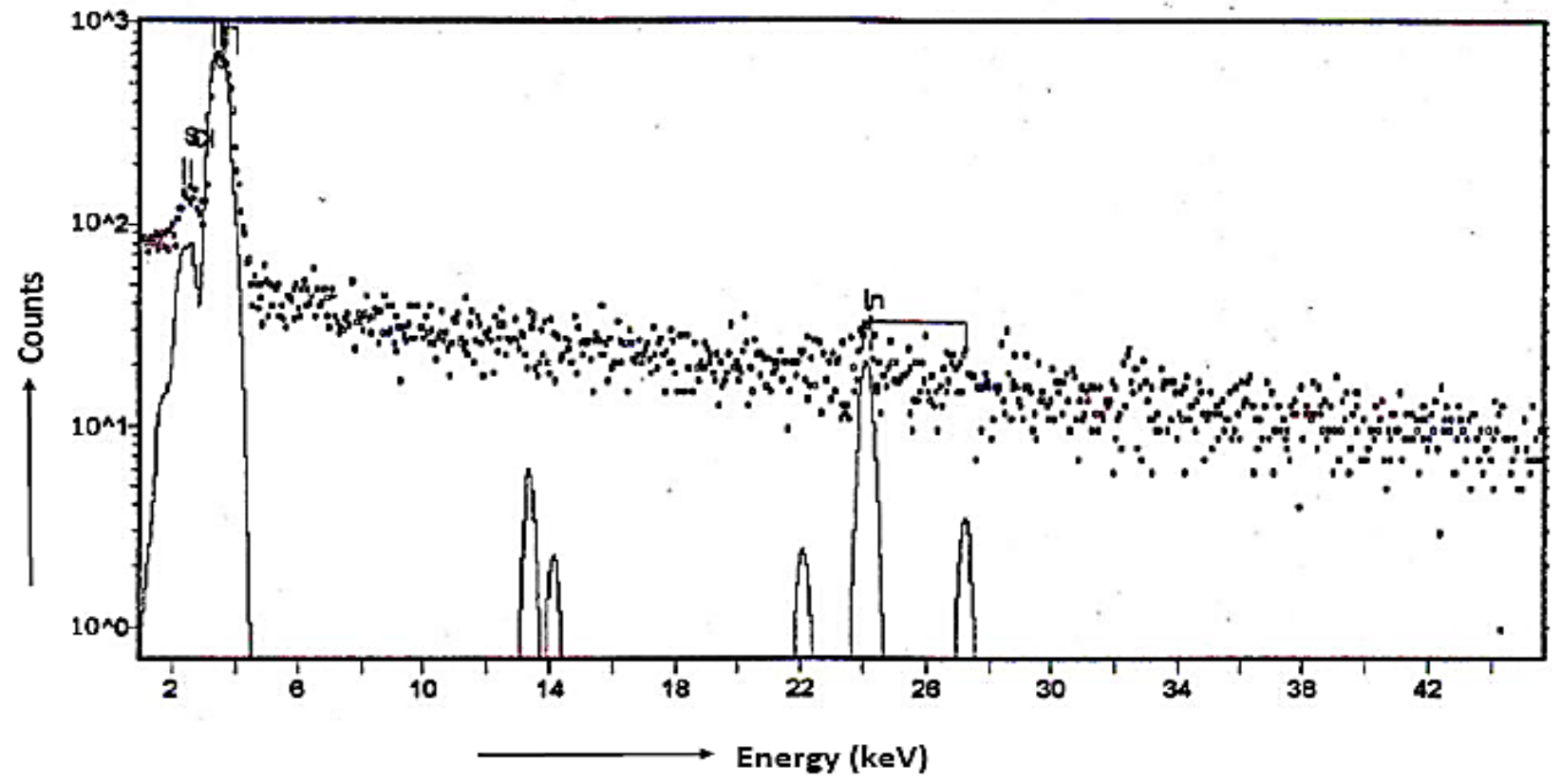

Figure 4: Typical PIXE spectrum of Mimosa pudica (bough). 
International Journal of Agriculture and Environmental Research

ISSN: 2455-6939

Volume: 07, Issue: 01 "January-February 2021"

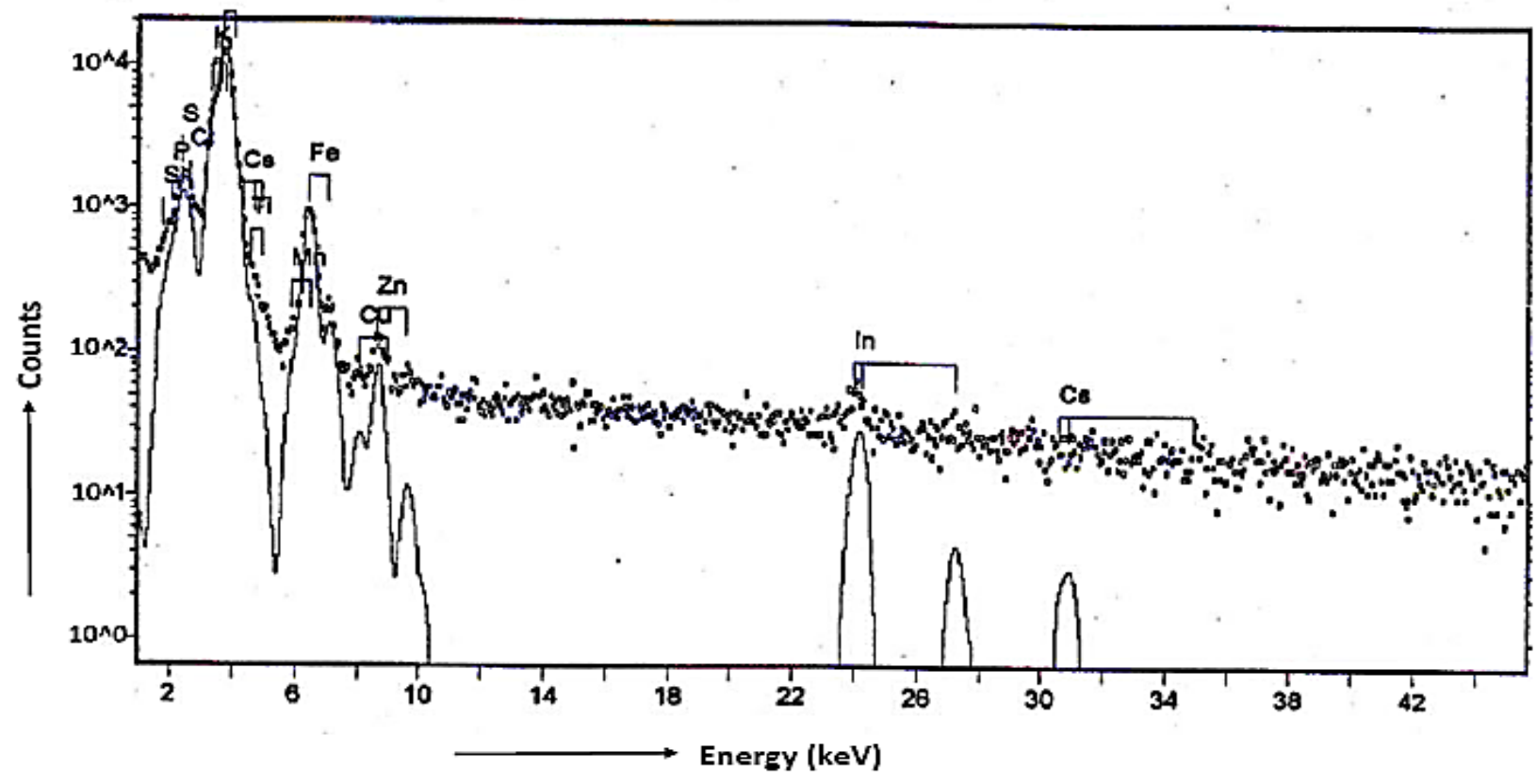

Figure 5: A Typical PIXE spectrum of Mimosa pudica (root).

\subsection{Concentration Measurement}

For PIXE technique we used MESTRO-32 (Ortec, USA, version 6.05) software for unfolding the $\mathrm{X}$-ray spectra. The acquired data were saved in a special GUPIX file format with some necessary header information, in the pre-defined folder. Then Dan32 window was used and results in a spreadsheet in an active mode. All the necessary information to run GUIPIX for PIXE analysis was written in each file-header and in the DAN-32 database. Therefore, we may calculate the concentration of various elements in samples of plant species utilizing GUPIX file format by some parameters. For background removal, the blank spectra were subtracted from each of the elemental spectra. Then identifying different elements in the spectrum, we found the net area/yield of that peak with MESTRO software, and the spectra data were normalized by charge. Putting the values of the concentration of the standard sample, $\mathrm{C}_{\mathrm{st}}, \mathrm{S}_{\mathrm{s}}$ the stopping powers of the sample, stopping power of the standard, $S_{\mathrm{st}}$, the yield of the sample, $\mathrm{Y}_{\mathrm{s}}$ and the yield of the standard, $Y_{\text {st }}$ in the following equation we determined the concentration of the elements [18][19].

$$
\mathrm{C}_{\mathrm{s}}=\mathrm{C}_{\mathrm{st}} \frac{S_{s} Y_{s}}{S_{s t} Y_{s t}}
$$




\section{RESULTS AND DISCUSSION}

The typical PIXE spectrum of selected medicinal plants such as Curcuma zedoarya (leaf), Curcuma zedoaria (bough), Euphorbia hirta (leaf), Mimosa pudica (bough), and Mimosa pudica (root) respectively are shown in Fig.1-Fig.5. Table.2 reveals the concentrations of different elements in the medicinal plants under analysis. $\mathrm{Al}, \mathrm{Si}, \mathrm{P}, \mathrm{S}, \mathrm{Cl}, \mathrm{K}, \mathrm{Ca}, \mathrm{Ti}, \mathrm{Mn}, \mathrm{Fe}, \mathrm{Zn}$ and $\mathrm{Ni}$ are among the elements detected at varying concentrations $(\mathrm{mg} / \mathrm{kg})$. Calcium is a crucial element for retaining healthy teeth and bones [20], Potassium is very important to develop the heart function and Calcium plays an essential role in the parameter of the water balance of the body [21].Calcium intake for children fed with calcium is about $33.7 \pm 2.0 \mathrm{mg} / 100 \mathrm{kcaline}$ in the first two months of life. For most of these beginners, calcium fence is estimated at $68 \pm 38 \mathrm{mg} / \mathrm{day}$ with an estimated urinary calcium [22] and natural excretion amounts. The largest percentage $(73431 \pm 338.60 \mathrm{mg} / \mathrm{kg}$ ) (Table 2) was reported in Mimosa pudica (Root) and the lowest value $(7059.8 \pm 176.19 \mathrm{mg} / \mathrm{kg}$ ) (Table 2) was identified in Curcuma zedoaria (Leaf). Figure 6,Ca illustrates that $10788.2 \pm 484.63 \mathrm{mg} / \mathrm{kg}$ was the measured concentration of $\mathrm{Ca}$ in medicinal plant specimens, which is higher than the acceptable IAEA-407 standards.Ca levels of $\mathrm{Al}$ for children of 4-8 years and 1-6 years are $780 \mathrm{mg} / \mathrm{day}$ and $500 \mathrm{mg} / \mathrm{day}$, respectively, RDAs of Ca for these identical age groups are 1000 and $650 \mathrm{mg} /$ day [23], respectively. Above 50years, 9-18 years and adults of 19-50 years are 1200, 1000 and $1300 \mathrm{mg} /$ day for $\mathrm{Al}$ and RDA levels of $\mathrm{Ca}$, respectively. Curcuma zedoaria cure Cold and Cough, sultry taste in the mouth, treat bronchitis and fevers [24]. In the scale of $245.5 \pm 2.29-533.7 \pm 105.04 \mathrm{mg} / \mathrm{kg}$ (Table 2), the largest volume of iron in any plant was identified to be the most effective iron. Iron Deficiency Toxicity involves a wide spectrum of disorders with diverse clinical effects [25], from kidney disease to iron excess, (Figure 6,Fe) as one of the most prevalent infections. As per Table 2, the overall concentration of Fe $245.5 \pm 2.29 \mathrm{mg} / \mathrm{kg}$ to is $533.7 \pm 105.04 \mathrm{mg} / \mathrm{kg}$, which is larger than both IAEA human intake limits.

Table 2: Comparison of Elemental concentrations (in $\mathrm{mg} / \mathrm{kg}$ ) between the measured value and reference materials of both IAEA-V10 and IAEA-359.

\begin{tabular}{cccccccc}
\hline Elements & $\begin{array}{c}\text { Curcuma } \\
\text { zedoaria } \\
\text { (Leaf) }\end{array}$ & $\begin{array}{c}\text { Curcuma } \\
\text { zedoaria(Bough) }\end{array}$ & $\begin{array}{c}\text { Euphorbia } \\
\text { hirta }(\text { Leaf) }\end{array}$ & $\begin{array}{c}\text { Mimosa pudica } \\
\text { (Bough) }\end{array}$ & $\begin{array}{c}\text { Mimosa pudica } \\
\text { (Root) }\end{array}$ & $\begin{array}{c}\text { IAEA- } \\
\text { V-10 }\end{array}$ & $\begin{array}{c}\text { IAEA- } \\
\mathbf{3 5 9}\end{array}$ \\
\hline $\mathrm{Al}$ & $4234.9 \pm 328.25$ & $3094.2 \pm 95.84$ & $30312.4 \pm 830.18$ & $\mathrm{ND}^{*}$ & $\mathrm{ND}^{*}$ & $\mathrm{NCV}^{\mathrm{a}}$ & $\mathrm{NCV}^{\mathrm{a}}$ \\
$\mathrm{Si}$ & $3999.8 \pm 115.48$ & $1572.7 \pm 121.85$ & $51180.4 \pm 246.01$ & $2975.3 \pm 126.69$ & $50536.8 \pm 188.72$ & $\mathrm{NCV}^{\mathrm{a}}$ & $\mathrm{NCV}^{\mathrm{a}}$ \\
$\mathrm{P}$ & $1694.2 \pm 52.88$ & $2550.8 \pm 63.04$ & $3011.2 \pm 11.64$ & $\mathrm{ND}^{*}$ & $3793.2 \pm 154.51$ & 2300 & $\mathrm{NCV}^{\mathrm{a}}$
\end{tabular}


International Journal of Agriculture and Environmental Research

ISSN: 2455-6939

Volume: 07, Issue: 01 "January-February 2021"

$\begin{array}{cccccccc}\mathrm{S} & 2927.3 \pm 89.37 & 1687.8 \pm 116.26 & 38281.3 \pm 399.43 & 3450.6 \pm 83.62 & 68740.7 \pm 514.61 & \mathrm{NCV}^{\mathrm{a}} & \mathrm{NCV}^{\mathrm{a}} \\ \mathrm{Cl} & 7419.9 \pm 150.04 & 2968.7 \pm 171.80 & 62529.8 \pm 536.58 & 2564.1 \pm 36.83 & 41055.8 \pm 762.15 & \mathrm{NCV} & \mathrm{NCV}^{\mathrm{a}} \\ \mathrm{K} & 8099.3 \pm 140.71 & 4005.1 \pm 107.73 & 32752.3 \pm 730.17 & 12034.3 \pm 250.71 & 49590.1 \pm 194.95 & 21000 & 32500 \\ \mathrm{Ca} & 7059.8 \pm 176.19 & \mathrm{ND} & \mathrm{ND} & 10788.2 \pm 484.63 & 73431 \pm 338.60 & 21600 & 18500 \\ \mathrm{Ti} & 6055.6 \pm 68.01 & 1962.6 \pm 72.69 & 58040.5 \pm 653.10 & \mathrm{ND} * & 48186.1 \pm 967.19 & \mathrm{NCV} & \mathrm{NCV}^{\mathrm{a}} \\ \mathrm{Mn} & 64.1 \pm 2.52 & 34.7 \pm 1.47 & 38.2 \pm 1.70 & 45 \pm 2.64 & 34.7 \pm 1.53 & 47 & 31.9 \\ \mathrm{Fe} & 497.8 \pm 5.88 & 245.5 \pm 2.29 & 322 \pm 22.61 & \mathrm{ND} * & 533.7 \pm 105.04 & 186 & 148 \\ \mathrm{Zn} & 55.2 \pm 2.96 & 28.02 \pm 1.00 & 57.8 \pm 1.58 & 24.9 \pm 2.53 & 18.8 \pm 1.70 & 24 & 38.6 \\ \mathrm{Ni} & \mathrm{ND} * & 24.5 \pm 1.80 & 44.4 \pm 2.94 & 25.3 \pm 1.53 & \mathrm{ND} * & \mathrm{NCV}^{\mathrm{a}} & \mathrm{NCV}^{\mathrm{a}}\end{array}$

ND*: Not Detected, $\mathrm{NCV}^{\mathrm{b}}$ : Non-certified Value, mean $\pm \mathrm{SD}(N=3), N=$ number of the samples analyzed for each plant, Calculation of standard deviation by origin software.

Reasonably high amounts of $\mathrm{Zn}$ were $18.8 \pm 1.70 \mathrm{mg} / \mathrm{kg}$ in Mimosa pudica (Root) and $57.8 \pm 1.58$ $\mathrm{mg} / \mathrm{kg}$ (Table 2) in Euphorbia hirta (Leaf) respectively. The actual allowable concentration of $\mathrm{Zn}$ is $24 \mathrm{mg} / \mathrm{kg}$ as per IAEA-V-10 and the mean amount measured $(38.6 \mathrm{mg} / \mathrm{kg})$ is lower than the recommended.

International Journal of Agriculture and Environmental Research

ISSN: 2455-6939

Volume: 07, Issue: 01 "January-February 2021"
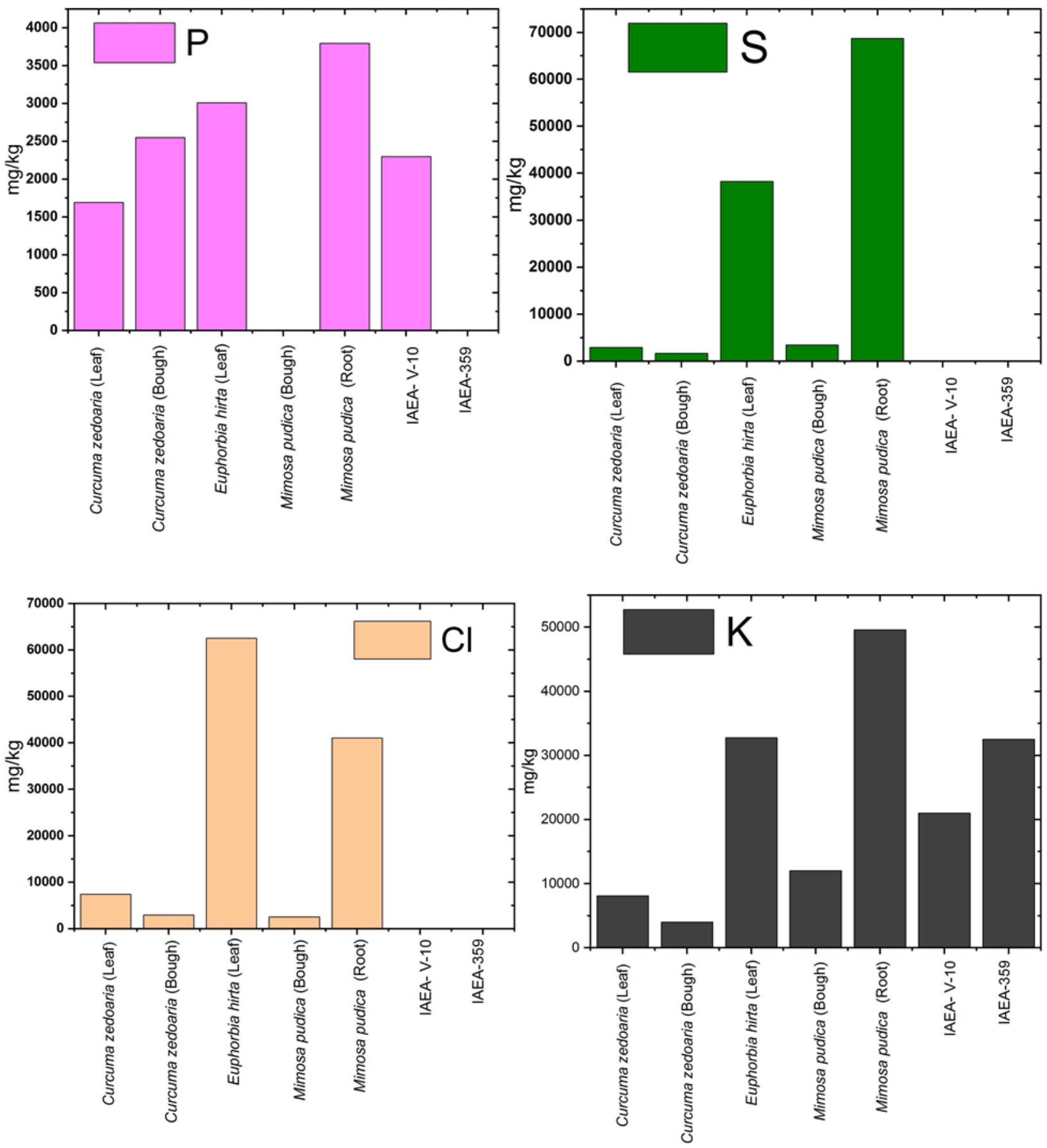
International Journal of Agriculture and Environmental Research

ISSN: 2455-6939

Volume: 07, Issue: 01 "January-February 2021"
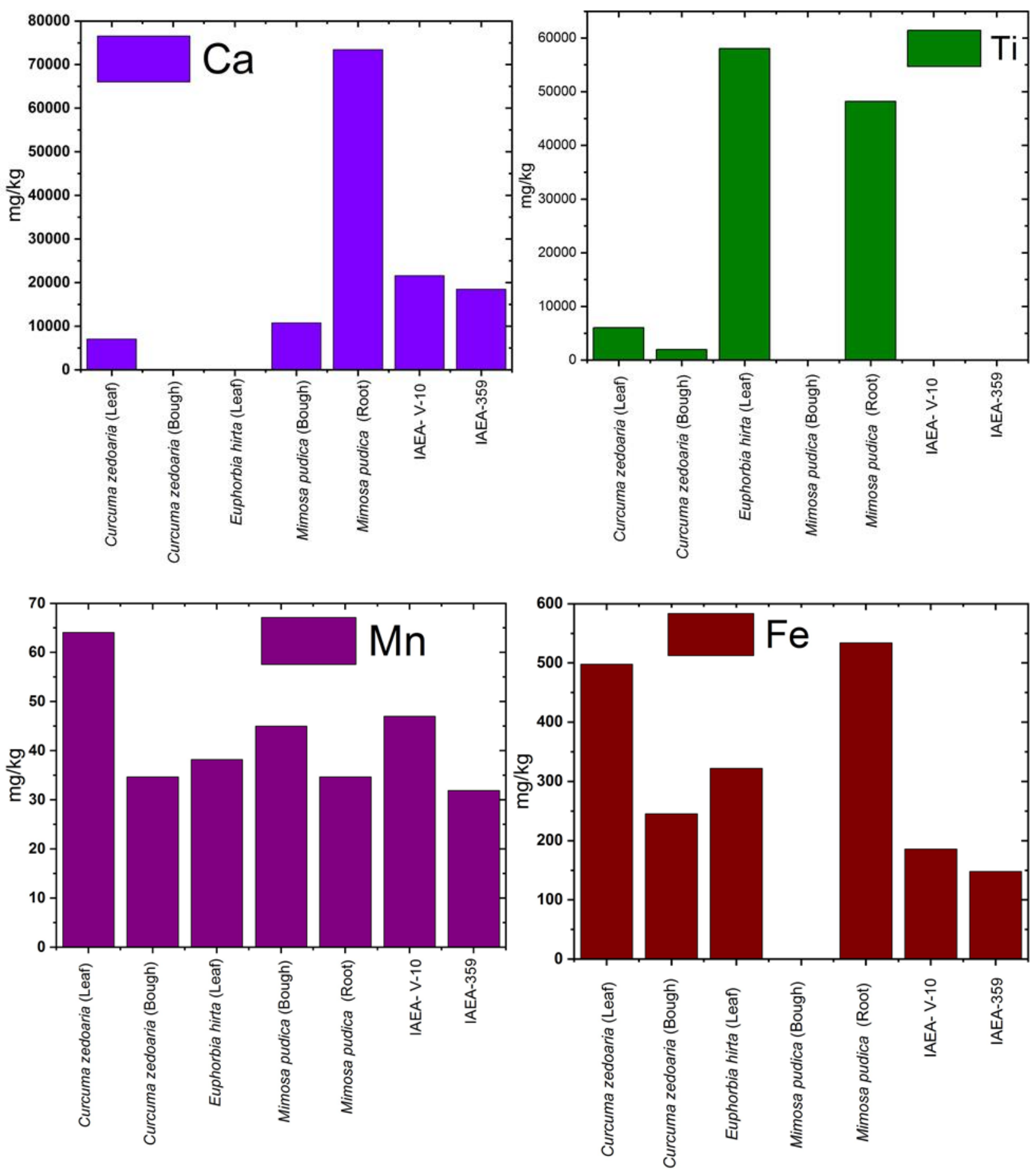

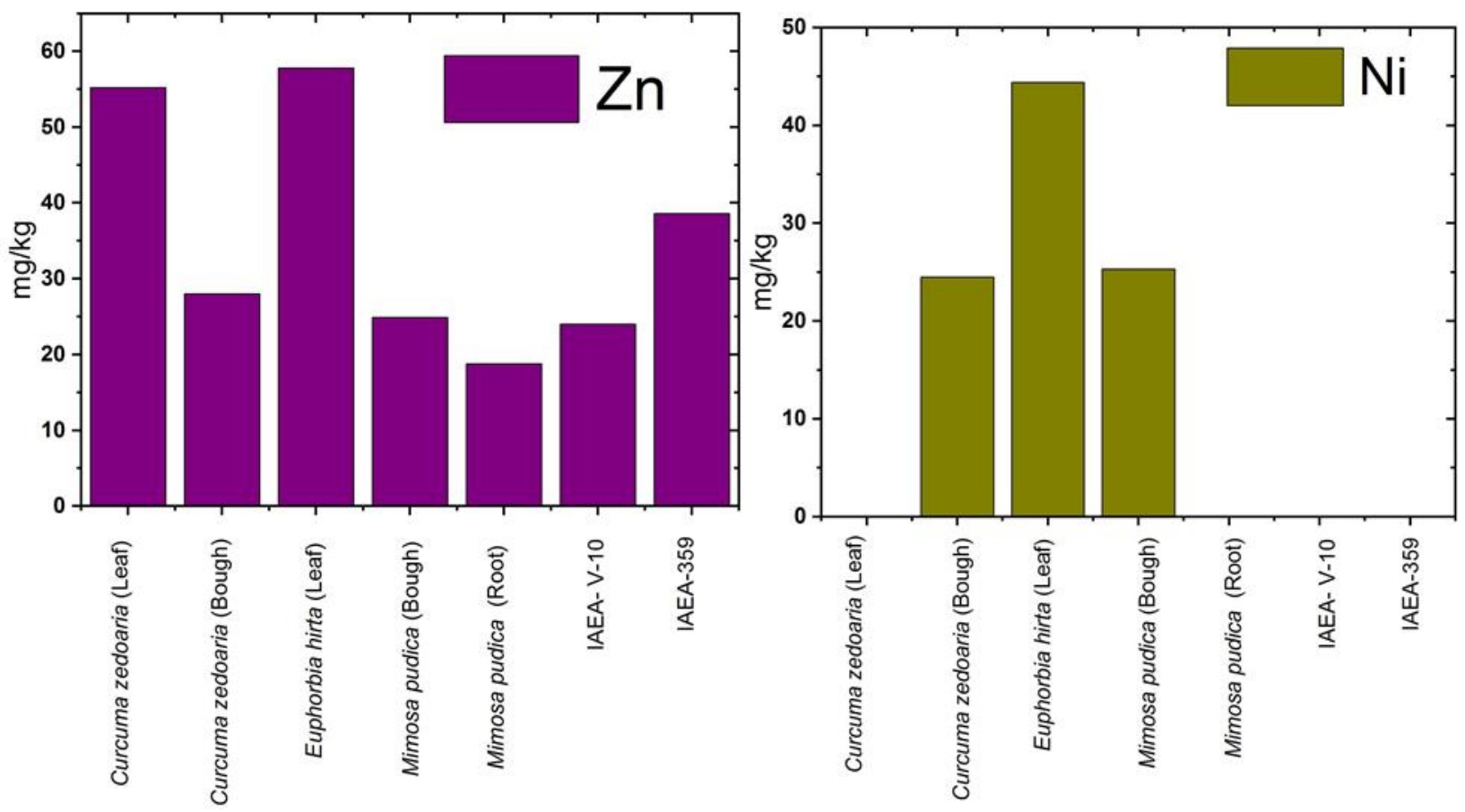

Figure 6: Distribution levels (mg/kg) of trace and heavy elements in selected Medicinal plants and compares with IAEA-V-10 and IAEA-359.

reasonable human intake level of IAEA-359 (Figure 6,Zn) when this value is within the safe limits of IAEA-359. In relation, zinc deficiency can occur and detrimental to nerve development, formation, and immunity, [26] but in extreme cases, it is fatal, whereas injection with excessive experience is atypical. $2000 \mathrm{mg}$ /day is the minimum prescription for potassium for adults in the decent physical condition. Table 2 indicates potassium in all samples $(4005.1 \pm 107.73 \mathrm{mg} / \mathrm{kg}$ $49590.1 \pm 194.95 \mathrm{mg} / \mathrm{kg}$ ) determined by IAEA-V-10 to be suitable every day for the human body at $21000 \mathrm{mg} / \mathrm{kg}$ and $32500 \mathrm{mg} / \mathrm{kg}$ for the IAEA-359. The experimental value of $\mathrm{K}$ was slightly higher than the safe limits of IAEA-359. Muscle cramps, lack of appetite, and irregular heartbeat are initiated due to $\mathrm{K}$ deficiency [27], and improving heart function is important. The highest $\mathrm{Al}$ concentration was contained in Euphorbia hirta (Leaf) $(30312.4 \pm 830.18 \mathrm{mg} / \mathrm{kg}$ ) and Mimosa pudica (Bough) and Mimosa pudica (Root) (Figure 6,Al) were not detected. Aluminum is a chemical element that is important for healthy bones in the stomach and inhibits the absorption of phosphate in the stomach, which is limited by IAEA-V-10 and IAEA-359. In our bodies, it is a central mineral. Silicon is located in the cells responsible for cartilage and bone, [28] in the collagen contained in the skin and accountable for its elasticity, and throughout the connective tissue that supports the body's structures. Table $\mathbf{2}$ reveals silicon in all samples $(1572.7 \pm 121.85 \mathrm{mg} / \mathrm{kg}-51180.4 \pm 246.01 \mathrm{mg} / \mathrm{kg})$ determined not to be found in IAEA-V -10 and IAEA-359 studies. Phosphorus is a widespread mineral that is a significant component of the 
International Journal of Agriculture and Environmental Research

ISSN: 2455-6939

Volume: 07, Issue: 01 "January-February 2021"

body's essential energy supply, ATP. Several approaches use processes in the body that control phosphorus-containing components such as cAMP, cGMP, and IP3. In the range of $1694.2 \pm 52.88 \mathrm{mg} / \mathrm{kg}-3793.2 \pm 154.51 \mathrm{mg} / \mathrm{kg}$ (Figure 6,P), the highest amount of phosphorous in every plant was defined as the most successful P. The highest percentage of S $(68740.7 \pm 514.61$ $\mathrm{mg} / \mathrm{kg}$ ) (Table 2) was recorded in Mimosa pudica (Root) and the lowest $(1687.8 \pm 116.26 \mathrm{mg} / \mathrm{kg}$ ) (Table 2) was reported in Curcuma zedoaria (Bough). Chloride is known to be an essential, main mineral in the body, [29] demanding the consumption of 2.3 grams a day. Being an essential nutrient, it is important for the body to function. The comparatively high levels of $\mathrm{Cl}$ (Figure 6,Cl), were $62529.8 \pm 536.58 \mathrm{mg} / \mathrm{kg}$ in Euphorbia hirta (Leaf) and $2564.1 \pm 36.83 \mathrm{mg} / \mathrm{kg}$ in Mimosa pudica (Bough) respectively. There is a measurable amount of titanium in the human body, and it has been calculated that we take around $0.8 \mathrm{mg} / \mathrm{day}$ [30], but much of it moves through us without being adsorbed. The highest concentration of Ti was Euphorbia hirta (Leaf) $(58040.5 \pm 653.10 \mathrm{mg} / \mathrm{kg}$ ) (Figure 6,Ti), and the lowest concentration was Curcuma zedoaria (Bough) $(1962.6 \pm 72.69 \mathrm{mg} / \mathrm{kg})$. In certain food classes, manganese is a naturally occurring mineral that is present. While it is harmful at high doses [31], it plays a significant part in several role of the body, including bone health management and sugar production. As shown in Table 2 , IAEA-V-10 and IAEA-359, the total allowable concentration for $\mathrm{Mn}$ is $64.1 \pm 2.52 \mathrm{mg} / \mathrm{kg}$ and $34.7 \pm 1.53 \mathrm{mg} / \mathrm{kg}$, which is close to our human intake. The gastrointestinal tract does not consume any nickel in diet, and usually less than 10 percent of the nickel consumed by food. [32]. In vegetables and fruits, the maximum allowable $\mathrm{Ni}$ concentration is $0.5 \mathrm{mg} / \mathrm{kg}$. In the present analysis, the value of $\mathrm{Ni}$ found $(44.4 \pm 2.94 \mathrm{mg} / \mathrm{kg}$ ) in Euphorbia hirta (Leaf)exceeds the allowable limit of Ni intake as set out in the International Program on Chemical Safety (IPCS) in its Health and Safety Guide No 62.

In brief, for medicinal purposes, medicinal plants are well known, and people use them as medicines to treat various diseases, nutrition or dietary problems. In the analysis revealed, the elemental concentration of some heavy and trace elements was higher than that of the International Acceptable Limit, i.e. IAEA -V-10 and IAEA-359, respectively. These elements are essential for human health. A vast number of industries are situated in the studied area. The environmental Protection levels are not monitored regularly by authority. So, the significant increase in the toxicity of heavy metals in all plant samples due to the high volume of chemical waste and environmental pollution.

\section{CONCLUSION}

Determination of the elemental concentration i.e. $\mathrm{Al}, \mathrm{Si}, \mathrm{P}, \mathrm{S}, \mathrm{Cl}, \mathrm{K}, \mathrm{Ca}, \mathrm{Ti}, \mathrm{Mn}, \mathrm{Fe}, \mathrm{Zn}$ and $\mathrm{Ni}$ in medicinal plants using PIXE techniques are commonly utilized in the center region of Bangladesh. The results have been compared with permissible limits of International Atomic 
International Journal of Agriculture and Environmental Research

ISSN: 2455-6939

Volume: 07, Issue: 01 "January-February 2021"

Energy Agency (IAEA-V-10 and IAEA-359), and provided crucial knowledge on the elements for our metabolic processes and wellbeing, improving health and curing of diseases. The data collected in this work was expected to be a valuable resource for further investigations of such types of medicinal plants.

\section{ACKNOWLEDGMENT}

The authors are very thankful to Atomic Energy Centre, Dhaka (AECD), Bangladesh, for carrying out this research work.

\section{REFERENCES}

1) Fahad, S. M., Md Joynal Abedin, M. Mehade Hasan, Md Obaidur Rahman, SM Azharul Islam, MD MIR, MD AKRAMUZZAMAN, and M. RUSSELL. "Study of elemental profile of some medicinal plants of Bangladesh." Journal of Nuclear and Particle Physics 4, no. 1 (2014):1-6. http://article.sapub.org/10.5923.j.jnpp.20140401.01.html

2) Fahad, S. M., A. F. M. Islam, Mahiuddin Ahmed, Nizam Uddin, Md Alam, Md Khalik, Md Hossain, and Md Abedin. "Determination of elemental composition of Malabar spinach, lettuce, spinach, hyacinth bean, and cauliflower vegetables using proton induced X-ray emission technique at Savar subdistrict in Bangladesh." BioMed Research International 2015 (2015).https://doi.org/10.1155/2015/128256

3) Devi, RK Bhanisana, H. Nandakumar Sarma, and Sanjiv Kumar. "Investigation on trace and major elements in anti-asthmatic medicinal plants by PIXE and PIGE techniques." Nuclear Instruments and Methods in Physics Research Section B: Beam Interactions with Materials and Atoms 343 (2015): 163166.https://doi.org/10.1016/j.nimb.2014.11.077.

4) Rovner, Alisha J., et al. "High risk of vitamin D deficiency in children with sickle cell disease." Journal of the American Dietetic Association 108.9 (2008): 15121516.https://doi.org/10.1016/j.jada.2008.06.433.

5) C.L. Keen, T. Jue, C.D. Tran, J. Vogel, R.G. Downing, V. Iyengar, R.B. Rucker, Analytical methods: improvements Advancements and new horizons, J. Nutr. 133 (2003) 1574S1578. https://doi.org/10.1093/jn/133.5.1574S.

6) E.I. Obiajunwa, A.C. Adebajo, O.R. Omobuwajo, Essential and trace element contents of some Nigerian medicinal plants, J. Radioanal. Nucl. Chem. 252 (2002) 473476.https://doi.org/10.1023/a:1015838300859.

7) C.I. Yamashita, M. Saiki, J.A.A. Sertié, Elemental analysis of leaves and extracts of Casearia medicinal plants by instrumental neutron activation analysis, J. Radioanal. Nucl. Chem. 270 (2006) 181-186.https://doi.org/10.1007/s10967-006-0327-y. 
International Journal of Agriculture and Environmental Research

ISSN: 2455-6939

Volume: 07, Issue: 01 "January-February 2021"

8) M.M. Özcana, A. Ünvera, T. Uçarb, D. Arslana, Mineral content of some herbs and herbal teas by infusion and decoction, Food Chem. 106 (2008) 11201127.https://doi.org/10.1016/j.foodchem.2007.07.042.

9) I. Queralt, M. Ovejero, M.L. Carvalho, A.F. Marques, J.M. Llabrés, Quantitative determination of essential and trace element content of medicinal plants and their infusions by XRF and ICP techniques, X-ray Spectrom. 34 (2005) 213217.https://doi.org/10.1002/xrs.795.

10) Devi, K. Nomita, and H. Nandakumar Sarma. "PIXE-PIGE analysis of some Indian medicinal plants." Nuclear Instruments and Methods in Physics Research Section B: Beam Interactions with Materials and Atoms 268.11-12 (2010): 21442147.https://doi.org/10.1016/j.nimb.2010.02.036

11) Morabad, R. B., S. J. Patil, and R. R. Tapash. "First series transition elemental analysis in some therapeutically important medicinal plants by AAS method." J. Mater. Environ. Sci 4 (2013): 171-176.

12) J. Anderson, L. Young, E. Long, Potassium and Health, in Food and Nutrition Series, Colorado State University, Colorado, 2008.

13) W. Maenhaut, Applications of ion beam analysis in biology and medicine, A review, Nucl. Instr. and Meth. B 35 (1988) 388-403.https://doi.org/10.1016/0168-583X(88)90300-X

14) S.O. Olabanji, O.R. Omobuwajo, D. Ceccato, M.C. Buoso, M.D. Poli, G. Moschini, Analysis of some medicinal plants in South-western Nigeria using PIXE, J. Radioanal. Nucl. Chem. 270 (2006) 515-521.https://doi.org/10.1007/s10967-006-0457-2

15) K.N. Devi, H.N. Sarma, S. Kumar, Estimation of essential and trace elements in some medicinal plants by PIXE and PIGE techniques, Nucl. Instr. and Meth. B 266 (2008) 16051610.https://doi.org/10.1016/j.nimb.2007.12.004

16) C. Stih, I.V. Popescu, G. Busuioc, T. Badica, A. Olariu, G. Dima, Particle induced X-ray emmission (PIXE) analysis of Basella L Alba leaves, J. Radioanal. Nucl. Chem. 246 (2000) 445 447.https://doi.org/10.1023/a:1006796523789

17) Olabanji SO, Adesina SK, Ceccato D, Buoso MC, Moschini G. PIXE analysis of some medicinal plants usually extracted and drunk as a tea, beverage or used as spice or flavour in Nigeria. InMexico: Proceedings of the International Conference on PIXE and in Analytical Applications Puebla 2007 (pp. 25-9).

18) Campbell, J. L., et al. "An intercomparison of spectral data processing techniques in PIXE." Nuclear Instruments and Methods in Physics Research Section B: Beam Interactions with Materials and Atoms 14.2 (1986): 204-220.https://doi.org/10.1016/0168583X(86)90045-5

19) Bandhu, H. K., et al. "Elemental composition and sources of air pollution in the city of Chandigarh, India, using EDXRF and PIXE techniques." Nuclear Instruments and Methods 
International Journal of Agriculture and Environmental Research

ISSN: 2455-6939

Volume: 07, Issue: 01 "January-February 2021"

in Physics Research Section B: Beam Interactions with Materials and Atoms 160.1 (2000): 126-138.https://doi.org/10.1016/S0168-583X(99)00574-1

20) Vallet-Regi, Maria, and José María González-Calbet. "Calcium phosphates as substitution of bone tissues." Progress in solid state chemistry 32.1-2 (2004): 131.https://doi.org/10.1016/j.progsolidstchem.2004.07.001

21) Strange, Kevin. "Regulation of solute and water balance and cell volume in the central nervous system." Journal of the American Society of Nephrology 3.1 (1992): 12-27.

22) Sheftel, Alex D., Anne B. Mason, and Prem Ponka. "The long history of iron in the Universe and in health and disease." Biochimica et Biophysica Acta (BBA)-General Subjects 1820.3 (2012): 161-187.https://doi.org/10.1016/j.bbagen.2011.08.002

23) Vaidya, Gunvanti H., and U. K. Sheth. "Mimosa pudica (linn.) its medicinal value and pilot clinical use in patients with menorrhagia." Ancient Science of life 5.3 (1986): 156-160.

24) Allwood, G., G. L. Asherson, M. Jean Davey, and P. J. Goodford. "The early uptake of radioactive calcium by human lymphocytes treated with phytohaemagglutinin." Immunology 21, no. 3 (1971): 509.

25) Domingo, J. L., J. L. Paternain, J. M. Llobet, and J. Corbella. "The effects of aluminium ingestion on reproduction and postnatal survival in rats." Life sciences 41, no. 9 (1987): 1127-1131.https://doi.org/10.1016/0024-3205(87)90631-X

26) Macdonald, Helen M., Antonia C. Hardcastle, Ravin Jugdaohsingh, William D. Fraser, David M. Reid, and Jonathan J. Powell. "Dietary silicon interacts with oestrogen to influence bone health: evidence from the Aberdeen Prospective Osteoporosis Screening Study." Bone 50, no. 3 (2012): 681-687.https://doi.org/10.1016/j.bone.2011.11.020

27) Jugdaohsingh, Ravin, Katherine L. Tucker, Ning Qiao, L. Adrienne Cupples, Douglas P. Kiel, and Jonathan J. Powell. "Dietary silicon intake is positively associated with bone mineral density in men and premenopausal women of the Framingham Offspring cohort." Journal of Bone and Mineral Research 19, no. 2 (2004): 297307.DOI: 10.1359/JBMR.0301225

28) Parcell, Stephen. "Sulfur in human nutrition and applications in medicine." Alternative Medicine Review 7.1 (2002): 22-44.

29) Li, Weicheng, Qigui Niu, Hong Zhang, Zhe Tian, Yu Zhang, Yingxin Gao, Yu-You Li, Osamu Nishimura, and Min Yang. "UASB treatment of chemical synthesis-based pharmaceutical wastewater containing rich organic sulfur compounds and sulfate and associated microbial characteristics." Chemical Engineering Journal 260 (2015): 5563.https://doi.org/10.1016/j.cej.2014.08.085

30) Barker, Jeremy, M. Yazid Saidi, and Chariclea A. Scordilis-Kelley. "Method of making stabilized electrochemical cell active material of lithium manganese oxide." U.S. Patent No. 6,183,718. 6 Feb. 2001. 
31) Monsen ER. Iron nutrition and absorption: dietary factors which impact iron bioavailability. J Am Diet Assoc. 1988 Jul;88(7):786-90. PMID: 3290310.

32) Aschner, Judy L., and Michael Aschner. "Nutritional aspects of manganese homeostasis." Molecular aspects of medicine 26.4-5 (2005): 353-362. https://doi.org/10.1016/j.mam.2005.07.003 